\title{
Travel to Work, Travel to Play: On Russian Tourism, Travel, and Leisure
}

\section{DiAne P. KoEnKer}

In the introduction to this special issue, Diane P. Koenker discusses the interrelated categories of travel, tourism, and leisure, looking at contrasting definitions of the traveler and the tourist and situating Russian and Soviet experience in a broader literature. Among the themes raised in the issue's articles, she enumerates the quest for knowledge and the premium placed on knowledge-producing travel and leisure activities, the tension between normative values and the desire of tourists and travelers to create their own autonomous experiences, and the ways in which the socialist project revalorized the role of the collective touring experience. She also considers the ways in which travel created both national identities and cosmopolitan ones and discusses some of the implications of spatial and gender analysis for studies of travel, touring, and leisure away from home.

\section{The Origins of Russian Scenery: Volga River Tourism and Russian Landscape Aesthetics}

\section{Christopher Ely}

The essential idea of landscape, that a section of terrain can be appreciated as a visual or aesthetic object, is largely a phenomenon of modern history, tied to processes such as urbanization and the development of tourism. Although the appreciation of landscape in Russia was influenced by European aesthetics, Russia developed a unique approach to its own natural environment, and the Volga River played an important role in that process. When steamship tourism appeared on the Volga in the late nineteenth century, the river became a crucial location for the articulation of a new, scenic aesthetic. But this aesthetic competed with earlier views of Russian landscape, which held that the simple and unspectacular character of the native countryside contrasted favorably with the overly picturesque and inauthentic landscapes of western Europe. Images of the Volga that emerged in guidebooks, travelogues, and visual media took shape in attempts to negotiate between the touristic impulse to appreciate beautiful scenery and more established conceptions of Russian nature as appealing precisely in its lack of picturesqueness.

\section{Getting to Know "The Peoples of the USSR": Ethnographic Exhibits as Soviet Virtual Tourism, 1923-1934}

Francine Hirsch

In this article, Francine Hirsch examines the Ethnographic Department of the Russian Museum as a venue for virtual tourism, where museumgoers were able to become acquainted with "the Peoples of the USSR" and where Soviet ethnographers and Politprosvet activists attempted to work 
out an idealized narrative about the socialist transformation of the Soviet Union. Focusing on the period of the "Great Break," Hirsch investigates the role of "the narrative" in the process of Soviet state formation and the role of mass participation in facilitating Soviet authoritarian rule. Hirsch treats the "ideological front" as a dynamic realm and shows how ethnographers, activists, and museumgoers attempted to reconcile disparities between "the real" and "the ideal" in the Soviet Union. In addition, she evaluates how the Soviet developmentalist narrative evolved after 1931, as ethnographers attempted to formulate a nonbiological, sociohistorical explanation for the persistence of traditional culture among certain population groups in an effort to counter German racial theories.

\section{Knowing the "Local": Rockefeller Foundation Officers' Site Visits to Russia in the 1920s}

\section{SusAn Gross SOLOMON}

In December 1927, Alan Gregg set off for Moscow on behalf of the Rockefeller Foundation's Division of Medical Education to carry out a "survey of local conditions" in Soviet medical education. The visit, which had been five years in the making, was eagerly anticipated by foundation officials as the first opportunity to secure "reliable knowledge" about the new Russia. Once in the field, Gregg was confronted by important dilemmas of judgment. He had gone to Russia with a made-in-America model of medical education favored by Rockefeller Foundation officers. Was Soviet medical education a variant of the model or something radically new? In making judgments on this issue, Gregg spoke with a variety of actors involved at all levels of Soviet medical education. Which voices to credit, which to discount? Solomon examines Gregg's landmark voyage to Russia as an instance of the challenges that face expert travelers who seek to "know" a foreign l'ocale.

\section{Stalinist Westernizer? Aleksandr Arosev's Literary and Political Depictions of Europe}

\section{Michael David-Fox}

This article examines variegated depictions of Europe and the west produced in the 1920s and 1930s by Aleksandr Iakovlevich Arosev, an Old Bolshevik cultural official, writer, and diplomat. Arosev traveled and worked in many parts of Europe in the prewar emigration, in the 1920s and early 1930 s as Soviet ambassador to Prague and other European capitals, and during the years of the Popular Front as head of the All-Union Society for Cultural Ties Abroad (VOKS). The discussion refracts a muchasked question - what new sources say about attitudes toward the Soviet system - through a new prism, depictions of the outside world. Although Arosev's personal diary and unpublished reports on cultural diplomacy with European fellow-travelers suggest an often startling degree of admiration and affinity for the west, higher levels of hostility are expressed in 
his literary output, mass-produced pamphlets, and especially his letters to Iosif Stalin. Interpreting these disjunctures, David-Fox argues that Arosev took advantage of tensions within Soviet ideology to craft depictions of Europe for different audiences. Until his execution in 1938, it was not impossible for Arosev to be both a Stalinist and a westernizer, but the combination was perilous, painful, and difficult to sustain.

\section{"There's No Place Like Home": Soviet Tourism in Late Stalinism}

ANNE E. Gorsuch

In this article, Anne E. Gorsuch explores the nature and meaning of tourism in the difficult and hungry years of late Stalinism. In this period of Cold War anxiety, tourism was seen as a means of reinforcing Soviet identity. Moscow was a particular focus of Soviet patriotic education, but tourism also contributed to the construction of Soviet identity on the larger collective level of the Soviet Union. Tourism was also offered as part of the cultured "good life" due loyal Soviet citizens. In every case, tourists were reminded that it was only within the borders of the socialist homeland that Soviet citizens could let down their guard and be confident of a warm welcome.

\section{Contesting Capitalism at the Post-Soviet Dacha: The Meaning of Food Cultivation for Urban Russians}

\section{JANE Zavisca}

Nearly half of urban Russian households grow food on their dacha plots. This study investigates the meaning of this activity for both those who embrace it and those who reject it. Existing scholarship frames the postSoviet dacha as a survival strategy and debates its efficiency. Ethnographic evidence reveals that the dacha provides not simply a source of food but a discursive arena for debating the rationality and morality of the transition to a market economy. Due to their rich history, dachas may be interpreted as sites of production or of consumption, as economic necessities or status signifiers. This ambiguity makes dachas particularly salient in disputes over the proper relationship between economic power and social esteem in the shifting stratification order. 